\title{
The Impact of Ultraviolet-B Radiation on the Sugar Contents and Protective Enzymes in Acyrthosiphon pisum
}

\author{
Chunchun Li ${ }^{1}$, Weining Yuan ${ }^{1}$, Yuping Gou ${ }^{1}{ }^{\mathbb{D}}$, Kexin Zhang ${ }^{1}$, Qiangyan Zhang ${ }^{1}$, Jing-Jiang Zhou ${ }^{1,2}$ \\ and Changzhong Liu ${ }^{1, *(D)}$
}

\section{check for}

updates

Citation: Li, C.; Yuan, W.; Gou, Y.; Zhang, K.; Zhang, Q.; Zhou, J.-J.; Liu, C. The Impact of Ultraviolet-B Radiation on the Sugar Contents and Protective Enzymes in Acyrthosiphon pisum. Insects 2021, 12, 1053. https:// doi.org/10.3390/insects12121053

Received: 19 October 2021

Accepted: 23 November 2021

Published: 25 November 2021

Publisher's Note: MDPI stays neutral with regard to jurisdictional claims in published maps and institutional affiliations.

Copyright: (c) 2021 by the authors. Licensee MDPI, Basel, Switzerland. This article is an open access article distributed under the terms and conditions of the Creative Commons Attribution (CC BY) license (https:/ / creativecommons.org/licenses/by/ $4.0 /)$.
1 Biocontrol Engineering Laboratory of Crop Diseases and Pests of Gansu Province, College of Plant Protection, Gansu Agricultural University, Lanzhou 730070, China; lichch1992@163.com (C.L.); nanjueyuan@126.com (W.Y.); gouyp1988@163.com (Y.G.); zhangkx199404@163.com (K.Z.); zhangqiangyan2@163.com (Q.Z.); jjzhou@gsau.edu.cn (J.-J.Z.)

2 State Key Laboratory of Green Pesticide and Agricultural Bioengineering, Ministry of Education, Guizhou University, Huaxi District, Guiyang 550025, China

* Correspondence: liuchzh@gsau.edu.cn

Simple Summary: The decrease of stratospheric ozone contributes to a significant increase in solar ultraviolet (UV-B) radiation. This effect has led to investigation on the impact of increased UV-B radiation on insect physiology. Pea aphid is a worldwide important agricultural pest and is difficult to control due to its small size, high fecundity, and non-sexual reproduction. As such, there is a need for study of the effects of UV-B radiation on aphid physiology, to raise awareness of the mechanisms of aphid responses to UV-B stress. The results reported here revealed that UV-B radiation can lead to an increase in sugar contents in both red and green morphs of this aphid species, and confirmed the effects of UV-B radiation on aphid physiology by means of influencing protective enzyme activity.

Abstract: Natural and anthropogenic changes have been altering many environmental factors. These include the amount of solar radiation reaching the Earth's surface. However, the effects of solar radiation on insect physiology have received little attention. As a pest for agriculture and horticulture, aphids are one of the most difficult pest groups to control due to their small size, high fecundity, and non-sexual reproduction. Study of the effects of UV-B radiation on aphid physiology may provide alternative control strategies in pest management. In this study, we examined the effects of UV-B radiation on protein and sugar contents, as well as the activities of protective enzymes, of the red and green morphs of the pea aphid over eight generations. The results indicated a significant interaction between UV-B radiation and aphid generations. Exposure of the pea aphids to UV-B radiation caused a significant decrease in the protein content and a significant increase in the glycogen and trehalose contents at each generation as measured in whole aphid bioassays. The enzyme activity of superoxide dismutase (SOD), peroxidase (POD), and catalase (CAT) of the pea aphids changed significantly at each generation with UV-B treatments. The SOD activity increased over eight generations to the highest level at $\mathrm{G}_{7}$ generation. However, the enzyme activity of CAT first increased and then decreased with UV-B treatments, and POD mostly gradually decreased over the eight generations. Therefore, UV-B radiation is an environmental factor that could result in physiological changes of the pea aphid. Moreover, our study discovered that red and green aphids did not display a significant consistent difference in the response to the UV-B treatments. These results may prove useful in future studies especially for assessing their significance in the adaptation and management against UV-B radiation.

Keywords: Acyrthosiphon pisum; UV-B radiation; protein; glycogen; trehalose; enzyme activity

\section{Introduction}

The decrease of stratospheric ozone makes solar ultraviolet (UV-B) radiation increase significantly [1], and has great and sometimes adverse effects on the carbon and nitrogen 
cycle of the whole biosphere [2], living habitat [3], biological characteristics [4], physiology, and biochemistry [5], and this is likely to affect aphids.

In recent years, the destruction of the stratospheric ozone layer in the Earth's atmosphere by the emission of anthropogenically generated pollutants $[6,7]$ has greatly increased interest in the effects of solar ultraviolet radiation, especially ultraviolet-B (UV-B) radiation, which is considerably more harmful to living organisms than UV-A because of its shorter wavelength and consequently higher energy levels [8]. UV-B has a wide range of effects on the growth, biochemistry, physiology, and population structure of organisms. There is a consensus that gradual UV-B radiation intensity can result in serious climate change, including increase in global temperature, imbalances in natural ecosystems, and risks for the survival of living organisms [7]. An increasing body of evidence suggests that UV irradiation is one of the most ubiquitous environmental hazards affecting every organism [9]. It is considered to be an environmental factor that induces oxidative damages to organisms through the production of reactive oxygen species (ROS), and causes damage to DNA, membrane lipids, and proteins [10-14]. UV-B radiation has been reported to affect the metabolic rates of both Aedes albopictus and Culex pipiens, whose survival rate were also significantly lower in full-sun compared to shade and no UV-B conditions [5]. However, information about oxidative stress induced by UV irradiation in insects is scarce, including for aphids, and relatively few studies have examined the responses of protective enzymes in insects under UV irradiation.

The protective enzymes such as superoxide dismutase (SOD), peroxidase (POD), and catalase (CAT) are an important component of innate insect immunity. The main functions of these enzymes are to clear the free radicals from the body, and protect insects against the damage caused by reactive oxygen species (ROS) or other peroxide free radicals [15]. In addition, the activity of protective enzymes is often used as a measure of insect physiological state [16]. Under normal physiological conditions, these enzymes, and free radicals are maintained in a state of equilibrium in insects. However, when insects are exposed to UV-B [17,18], heat stress [19], insecticides [20,21], pathogens [22,23], the levels of the enzymes and free radical changes, and the protective enzymes are activated to decompose and metabolize free radicals, to maintain normal physiological activities in the body [24]. It has been reported that UV light irradiation induced superoxide radical and intensified the activity of protein oxidation processes in Helicoverpa armigera adults [17], and raised the activities of protective enzymes in its body to resist the damage of the radicals in the aphid Sitobion avenae [25].

The pea aphid, Acyrthosiphon pisum (Harris), is a soft-bodied hemimetabolous insect that is distributed globally. Furthermore, A. pisum has red and green body colour polymorphisms. The green pea aphid is widely distributed all over the world and has been reported since 1776 [26], while the red pea aphid was first reported by Harrington in 1945 [27]. Laboratory crosses between red and green morphs indicates that the body colour assay of pea aphids is genetically determined, and its morphs remain distinct between generations because the aphids reproduce parthenogenetically $[28,29]$. However, some environmental factors (e.g., symbiotic microorganisms) are also considered to affect aphid body colour [30].

A. pisum lives year-round under direct sunlight and is not capable of escaping from UV-B [5,31]. The aphids voraciously suck fluid from plants and secret honeydew, causing the leaves of plants to mould, wither, and even die, therefore reducing crop yields [32]. They can also transmit 25 types of viruses by sap-feeding, causing enormous production losses of cash crops [33]. In recent years, because of the influence of many factors (e.g., UV radiation), the pea aphid population has become one of the dominant pests in alfalfa (Medicago sativa), and the importance of the red pea aphid has gradually increased in China [34]. This has enhanced the research on the pea aphids [35-38], and on the effects of UV-B treatment on biological characteristics of aphids. Yuan et al., $[39,40]$ showed that ultraviolet radiation inhibited the growth and reproduction of pea aphids, and the effect of this inhibition was proportional to the radiation intensity and time. Moreover, with 
prolonged exposure to UV-B radiation over time, the average body length of red pea aphids was shortened, and the average weight reduced [40].

In the current study, we aimed to elucidate the effect of UV-B treatment on the sugar contents and protective enzyme activity in the red and green morphs of the pea aphid over eight generations. We compared the effect of UV-B treatments on the contents of protein, glycogen and trehalose, and the activity of SOD, POD, and CAT in the red and green morphs. This study helps to inform approaches for further study of the defense mechanism of the pea aphids to environmental changes and support the development of new approaches for pest management.

\section{Materials and Methods}

\subsection{Insect Culture}

The initial population of the pea aphids Acyrthosiphon pisum Harris used in this study was established from a single parthenogenetic female collected from an alfalfa field in Gansu Province, China, and maintained in Biocontrol Engineering Laboratory of Crop Diseases and Pests. The pea aphids were reared on the fava bean plant (Vicia faba L.) leaves in the laboratory for eight generations. Briefly, leaves of fava bean were placed on a Petri dish $(9 \mathrm{~cm}$ in diameter) with a piece of moist absorbent cotton around the petioles and the back side of the leaf facing up. The red and green aphids sourced from these leaves were then separately introduced into the additional Petri dishes with bean leaves and reared separately in two incubators at $25 \pm 1{ }^{\circ} \mathrm{C}, 70 \%$ relative humidity and a photoperiod of $16 \mathrm{~L}$ : $8 \mathrm{D}$. Adult pea aphids that molted within $12 \mathrm{~h}$ from 4 th instar aphids were used for tests.

\subsection{Mode of $U V-B$ Treatment}

A UV-B lamp (Hebei Zhonglian Qitong Information Technology Co., Ltd., ZW40D17W, Hebei, China) was used as the source of artificial UV-B radiation. The nymphs $(<12 \mathrm{~h})$ produced by the adult aphids were fed on bean leaves for $12 \mathrm{~h}$ and then treated at $4 \mathrm{~W} / \mathrm{m}^{2}$ intensity of UV-B radiation for $20 \mathrm{~min}, 30 \mathrm{~min}, 40 \mathrm{~min}$, and $50 \mathrm{~min}$. The distance between the aphids and the UV-B lamp was $30 \mathrm{~cm}$. The aphids treated under an incandescent lamp at $4 \mathrm{~W} / \mathrm{m}^{2}$ intensity (New Light Source Lighting Technology Co., Ltd., ST58, Haining, China) were served as control. The UV-B treatment and the control treatment were performed with 20 either red or green aphid morphs in a Petri dish with leaves for each exposure duration. The aphids were irradiated once a day for the specific exposure duration until the adult stage (about 6 days). All treatments were repeated 3 times.

After 6-day exposure, five red aphids and five green adult aphids were collected as $\mathrm{G}_{0}$ treated aphids from each dish and stored at $-80^{\circ} \mathrm{C}$ for the following experiments. Then the newly emerged $(<12 \mathrm{~h})$ nymphs from the remaining adult aphids were transferred to new Petri dishes with fresh leaves and used for next run of the UV-B treatments. This test procedure was repeated 8 times, and produced aphids were used to the treatment for 8 -generation $\left(G_{0}-G_{7}\right)$. A total of 2400 nymphs $(20$ nymphs $\times 5$ treatments $\times 3$ replicates $\times$ 8 generations) was used in this experiment.

\subsection{Determination of Trehalose and Glycogen Content}

The measurements of trehalose and glycogen contents in the red and green aphid morphs were determined mainly following the method used by Handel \& Day [41]. Five adult aphids from each generation stored at $-80^{\circ} \mathrm{C}$ were rinsed with sterile distilled water and placed on filter paper to absorb the moisture on the surface of the aphids. After the aphids were weighed, they were put together in a $1.5 \mathrm{~mL}$ centrifuge tube containing $50 \mu \mathrm{L}$ of $10 \%$ trichloroacetic acid. The aphids were then ground with a grinding stick in the centrifuge tube. A total of $350 \mu \mathrm{L}$ of $10 \%$ trichloroacetic acid solution was used to wash the grinding stick twice and added into the centrifuge tube. The aphid homogenate was then centrifuged at $5000 \mathrm{rpm}$ for $5 \mathrm{~min}$ at $20^{\circ} \mathrm{C}$. The supernatant was transferred to a new $1.5 \mathrm{~mL}$ centrifuge tube, and the precipitate was discarded. Then, $800 \mu \mathrm{L}$ of absolute ethanol was added to the supernatant, mixed and incubated at $4{ }^{\circ} \mathrm{C}$ overnight (about $16-17 \mathrm{~h}$ ). 
Next day, the mixture was centrifuged at 10,000 rpm for $20 \mathrm{~min}$. The resulting supernatant was transferred to a $1.5 \mathrm{~mL}$ centrifuge tube and used as the trehalose assay solution. The white precipitate was dissolved in $1000 \mu \mathrm{L}$ of sterile distilled water and transferred to another $1.5 \mathrm{~mL}$ centrifuge tube as glycogen assay solution.

$200 \mu \mathrm{L}$ of the trehalose assay solution was mixed with $1000 \mu \mathrm{L}$ of $0.15 \mathrm{~N} \mathrm{H}_{2} \mathrm{SO}_{4}$ solution and heated in a boiling water bath for $10 \mathrm{~min}$. After the mixture was cooled down, $1000 \mu \mathrm{L}$ of $30 \% \mathrm{KOH}$ was added. Then the mixture was boiled in a water bath for $10 \mathrm{~min}$, and kept at room temperature for $20 \mathrm{~min}$. The resulting solution $(200 \mu \mathrm{L})$ was added to the microplate. The trehalose content and glycogen content were determined by measuring the absorbance value of the samples at $620 \mathrm{~nm}$ and $630 \mathrm{~nm}$, respectively, with the spectrophotometer (Koromee Scientific Instruments Co., Ltd., UV-6100, Shanghai, China). The trehalose and glycogen contents were calculated from the absorbance value using D-glucose as standard. Each UV-B treatment was repeated three times.

\subsection{Preparation of Enzyme Solution}

The red and green adult aphids from each generation were collected as described above. The aphids ( $n=5$ for each colour morph) were weighed and together placed in a precooled test tube, and then $1 \mathrm{~mL}$ of $50 \mathrm{mmol} / \mathrm{L}$ phosphate buffered saline (PBS, pH 7.8) was added to create a suspension. The suspension was ground using a glass homogenizer in an ice bath, homogenized by ultrasonic disruption for $10 \mathrm{~min}$, and centrifuged at 10,000 rpm at $4{ }^{\circ} \mathrm{C}$ for $10 \mathrm{~min}$. The supernatant was collected, stored at $-80^{\circ} \mathrm{C}$ and used as the enzyme solutions to measure the total amount of protein and the activity of protective enzymes.

\subsection{Protein Content Determination}

Protein content in red and green aphids were determined according to Lowry et al. methods [42]. Seven different concentrations $(0,0.02,0.04,0.06,0.08,0.10$, and $0.12 \mathrm{mg} / \mathrm{mL})$ of the bovine serum albumin (BSA) (99.5\%, Hubei Jiufenglong Chemical Co., Ltd., Wuhan, China), were used to construct the standard curve. About $50 \mu \mathrm{L}$ of the enzyme solution was transferred into a well of 96-well microplate and addition of $200 \mu \mathrm{L}$ Coomassie brilliant blue G-250 to each well. The protein concentration was quantified spectrophotometrically at $595 \mathrm{~nm}$. The protein contents were calculated based on the standard curve of BSA. Each UV-B treatment for each morph and each generation was repeated three times.

\subsection{Protective Enzyme Activities of Pea Aphids}

The superoxide dismutase (SOD) activity was determined according to Beauchamp \& Fridovich methods [43]. We mixed $125 \mu \mathrm{L}$ of the reaction fluid with $5 \mu \mathrm{L}$ of the enzyme solution and $50 \mu \mathrm{L}$ of $13 \mathrm{mmol} / \mathrm{L}$ riboflavin. The $5 \mu \mathrm{L}$ enzyme solution was replaced with $5 \mu \mathrm{L}$ of $50 \mathrm{mM}$ PBS in the control groups. After $15 \mathrm{~min}$ exposure to light at $4000 \mathrm{Lx}$ and $25^{\circ} \mathrm{C}$, the solution was immediately protected from light and the absorbance at $\mathrm{OD}_{560}$ of the solution was determined immediately. The measurement was measured 3 times. The SOD enzyme activity was then measured as the $\mathrm{OD}_{560}$ value and calculated using the amount of enzyme required for $50 \%$ inhibition as an enzyme activity unit (U). Enzyme activity was expressed as the change in the $\mathrm{OD}_{560}$ value per unit of time and unit of protein.

The catalase (CAT) activity was determined according to Chance \& Maehly methods [44]. In short, $100 \mu \mathrm{L}$ of $\mathrm{H}_{2} \mathrm{O}_{2}(8 \%)$ solution mixed with to $190 \mu \mathrm{L}$ of $50 \mathrm{mM}$ PBS ( $\mathrm{pH}$ 7.8). Then, $10 \mu \mathrm{L}$ of the enzyme solution was added to the mixture. The OD240 was measured immediately at $25{ }^{\circ} \mathrm{C}$ every $1 \mathrm{~min}$ for $3 \mathrm{~min}$. In the control group, the PBS buffer was used instead of the enzyme solution. The experiment was repeated 3 times. The amount of enzyme that reduces OD240 by 0.1 unit in $1 \mathrm{~min}$ is expressed as 1 unit of CAT activity.

The peroxidase (POD) activity was determined according to Shan et al. [45]. The sample mixture contained $235 \mu \mathrm{L}$ of $50 \mathrm{mM}$ PBS buffer ( $\mathrm{pH} 7.8$ ), $20 \mu \mathrm{L}$ guaiacol and $15 \mu \mathrm{L}$ of the enzyme solution. Subsequently, $15 \mu \mathrm{L}$ of $26 \mathrm{mM} \mathrm{H}_{2} \mathrm{O}_{2}$ was quickly added. The samples were placed at room temperature for $5 \mathrm{~min}$, and the colorimetry was measured 
at a wavelength of $470 \mathrm{~nm}$ every $1 \mathrm{~min}$ for $10 \mathrm{~min}$. The reactions were measured 3 times. The POD activity was expressed as an increase of 0.01 of A470 per minute. The control consisted of the PBS buffer instead of enzyme solution.

\subsection{Statistical Analysis}

Data were expressed as a mean \pm standard deviation (S.D.) for the 3 replicates for the 2 colour morphs, 8 generations, and 4 treatment times. All statistical analyses were performed using IBM SPSS Statistics version 23.0 (Chicago, IL, USA), with UV-B treatment, and generation included as factors. The general linear model (GML) procedure of the Statistical Analysis System (SAS) (https://www.sas.com/en_us/home.html; accessed on 29 July 2021) was used to analyze the means when a significant interaction between generations and UV-B treatments. One-way ANOVA was conducted to examine the effects of UV-B radiation treatment and generation on the test parameters (protective enzyme activity, sugar and protein contents) followed by Tukey's honestly significant difference (HSD) test. In addition, these test parameters were compared between $G_{0}$ and $G_{7}$ on red and green morphs, respectively. Differences between the means were tested for significance at the 0.05 significance level.

\section{Results}

\subsection{Interaction between $U V-B$ Treatment and Generation}

There was a statistically significant interaction between the UV-B treatment and growth generation on the glycogen content, the protein content, the SOD activity, and the CAT activity of both aphid colour morphs $(p<0.001)$ (Table 1$)$. The interaction of the two factors (generation and UV-B treatment) was not significant only in the green aphids for the trehalose content $(\mathrm{F}=1.48, \mathrm{df}=28, p>0.05)$ and in the red aphids for the POD activity $(\mathrm{F}=0.54, \mathrm{df}=28, p>0.05)$. Therefore, we used one-way ANOVA and Tukey's HSD test to separately compare the effect of UV-B treatment at $G_{0}-G_{7}$ generation and the effect of growth generation under different UV-B treatment.

Table 1. Summary of analysis of two factors ANOVA results for effects of UV-B and generation interaction on the sugar contents and protective enzymes in A. pisum.

\begin{tabular}{ccccccc}
\hline Measurement & Morph & Type III Sum of Squares & Df & Mean Square & $\boldsymbol{F}$-Value & $\boldsymbol{p}$-Value \\
\hline \multirow{2}{*}{ Trehalose } & Red & 1.61 & 28 & 0.06 & 2.85 & $<0.001$ \\
& Green & 0.80 & 28 & 0.03 & 1.48 & 0.089 \\
Glycogen & Red & 4.62 & 28 & 0.17 & 3.89 & $<0.001$ \\
& Green & 2.66 & 28 & 0.10 & 4.88 & $<0.001$ \\
\multirow{2}{*}{ Protein } & Red & 489.78 & 28 & 17.49 & 12.09 & $<0.001$ \\
& Green & 352.13 & 28 & 12.58 & 12.91 & $<0.001$ \\
SOD & Red & 701.47 & 28 & 25.05 & 54.56 & $<0.001$ \\
& Green & 300.34 & 28 & 10.73 & 31.71 & $<0.001$ \\
POD & Red & 3.28 & 28 & 0.12 & 0.54 & 0.966 \\
& Green & 20.08 & 28 & 0.72 & 1.78 & 0.024 \\
CAT & Red & 36.92 & 28 & 1.32 & 4.90 & $<0.001$ \\
& Green & 27.46 & 28 & 0.98 & 2.88 & $<0.001$ \\
\hline
\end{tabular}

\subsection{Effects of UV-B Treatments on the Trehalose Content of Aphids}

Overall, the trehalose content increased with the duration of the UV-B treatments (20-50 $\mathrm{min}$ ) for each generation $\left(\mathrm{G}_{0}-\mathrm{G}_{7}\right)$, and it peaked with the $50 \mathrm{~min}$ UV-B treatment at $\mathrm{G}_{7}$ generation (Figure $\left.1 \mathrm{~A}, \mathrm{~B}\right)$. During earlier generations $\left(\mathrm{G}_{0}-\mathrm{G}_{3}\right)$ the trehalose content of the UV-B treated red aphids dropped with increasing generation, the lowest trehalose content was seen at $\mathrm{G}_{3}$ generation. Then, the trehalose content began to increase with the generation under most UV-B treatments (Figures $1 \mathrm{~A}$ and $\mathrm{S} 1 \mathrm{~A}$ ). At $\mathrm{G}_{7}$ generation, the trehalose content was significantly higher in the $30 \mathrm{~min}-50 \mathrm{~min}$ treated red aphids than in untreated control aphids and increased significantly from $1.55 \pm 0.05 \mu \mathrm{g} / \mathrm{mg}$ in the $30 \mathrm{~min}$ treated aphids to $1.65 \pm 0.08 \mu \mathrm{g} / \mathrm{mg}$ and $1.95 \pm 0.04 \mu \mathrm{g} / \mathrm{mg}$ in the $40 \mathrm{~min}$ and $50 \mathrm{~min}$ treated aphids, respectively, 1.74-2.19 times higher than that of the control aphids (Figure 1A). Like in the red aphids, the trehalose content in the UV-B treated green aphids was also highest in the 
50 min treated aphids for each generation. However, unlike the U-shape response in the treated red aphids, the shape of the trehalose content is indeterminate over generations in the treated green aphids (Figures $1 \mathrm{~B}$ and S1B). There was no significant difference in the trehalose contents between the $20 \mathrm{~min}$ UV-B treated and untreated control aphids, but in the $30 \mathrm{~min}-50 \mathrm{~min}$ UV-B treated aphids, the change of trehalose content was significant, and the content was higher compared to that of untreated aphids (Figure S1A,B).
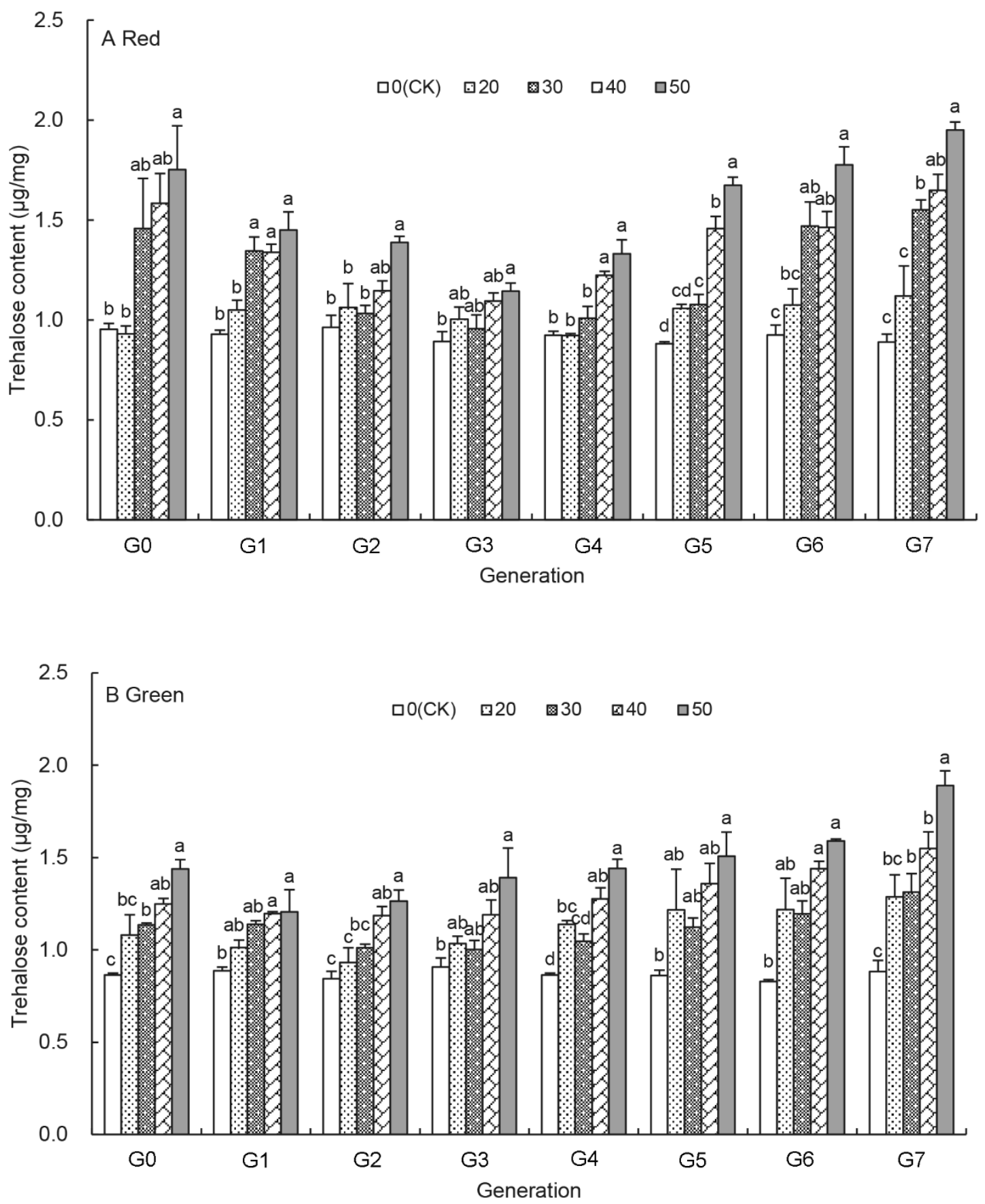

Figure 1. Effects of UV-B radiation on the trehalose content of A. pisum at each generation $\left(\mathrm{G}_{0}-\mathrm{G}_{7}\right)$. Different lowercase letters between UV-B radiation are statistically different at a same generation in red (A) and green (B) A. pisum ( $p<0.05$, Tukey-HSD test). 


\subsection{Effects of UV-B Treatments on the Glycogen Content of Aphids}

For the red colour morph, Figure 2A reveals that the glycogen content increased as the UV-B treatment duration increased from $20 \mathrm{~min}$ to $50 \mathrm{~min}$ in each generation and was significantly higher than that of untreated aphids after $\mathrm{G}_{4}$ generation (Figure 2A). Moreover, the glycogen content in untreated aphid was relatively stable over generations, whereas it increased from $G_{0}$ to $G_{7}$ generation at each UV-B treatment in the UV-B treated aphids (Figure $\mathrm{S} 2 \mathrm{~A}$ ). At $\mathrm{G}_{7}$ generation, the glycogen content had increased significantly by the UV-B treatment and ranged from $2.50 \pm 0.13 \mu \mathrm{g} / \mathrm{mg}$ for the $20 \mathrm{~min}$ treatment to $3.39 \pm 0.06 \mu \mathrm{g} / \mathrm{mg}$ for the $50 \mathrm{~min}$ treatment, which was 1.80-2.44 times higher than those of the untreated aphids (Figure 2A).
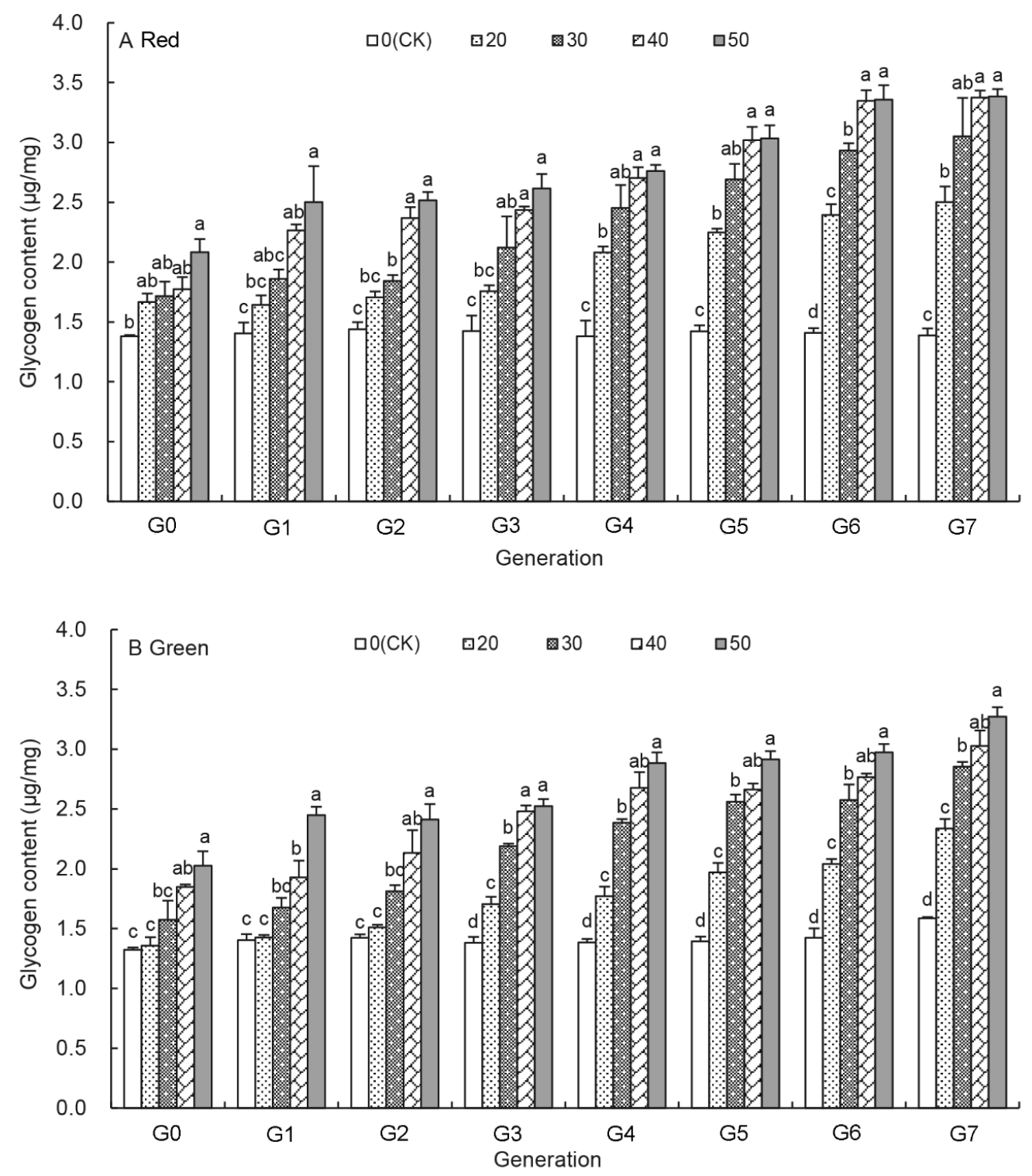

Figure 2. Effects of UV-B radiation on the glycogen content of $A$. pisum at each generation $\left(\mathrm{G}_{0}-\mathrm{G}_{7}\right)$. Different lowercase letters between UV-B radiation are statistically different at a same generation in red (A) and green (B) A. pisum ( $p<0.05$, Tukey-HSD test).

Figure 2B shows that the effect of UV-B treatments on the glycogen content in the green pea aphids. Like the red aphids after UV-B treatments, the glycogen content in the treated green aphids increased with the prolonged UV-B treatments at each generation and increased as the generation progressed at same UV-B treatment (Figures 2B and S2B). The 
glycogen content at $G_{7}$ generation was the highest under each UV-B treatment, which was 1.47-2.06 times higher that of the untreated control aphids (Figure 2B).

\subsection{Effects of UV-B Treatments on the Protein Content of Aphids}

The protein content of the red and green aphids before and after UV-B treatments is shown in Figure 3. It ranged from $23.75 \pm 0.29 \mu \mathrm{g} / \mathrm{mg}$ to $46.28 \pm 0.11 \mu \mathrm{g} / \mathrm{mg}$ in the red aphids, and $27.09 \pm 0.24 \mu \mathrm{g} / \mathrm{mg}$ to $45.02 \pm 0.28 \mu \mathrm{g} / \mathrm{mg}$ in the green aphids (Figure $3 \mathrm{~A}, \mathrm{~B}$ ). In both aphids, the protein content first increased, then decreased under the UV-B treatments in $\mathrm{G}_{0}$ to $\mathrm{G}_{4}$ generation (also Table S1). The highest protein content occurred in the $20 \mathrm{~min}$ treatment at $\mathrm{G}_{3}$ generation for both aphids. After $\mathrm{G}_{3}$ generation it gradually decreased with increasing generation with the lowest protein level recorded with UV-B treatment duration of the 50 min treatment at $G_{7}$ generation. Compared with those of untreated aphids, the protein content was significantly reduced by $8.77-33.69 \%$ in the treated red aphids, and $12.56-25.70 \%$ in the treated green aphids at $\mathrm{G}_{6}$ and $\mathrm{G}_{7}$ generation. However, without the UV-B treatments (control), the protein content remained stable over generations in both aphids.
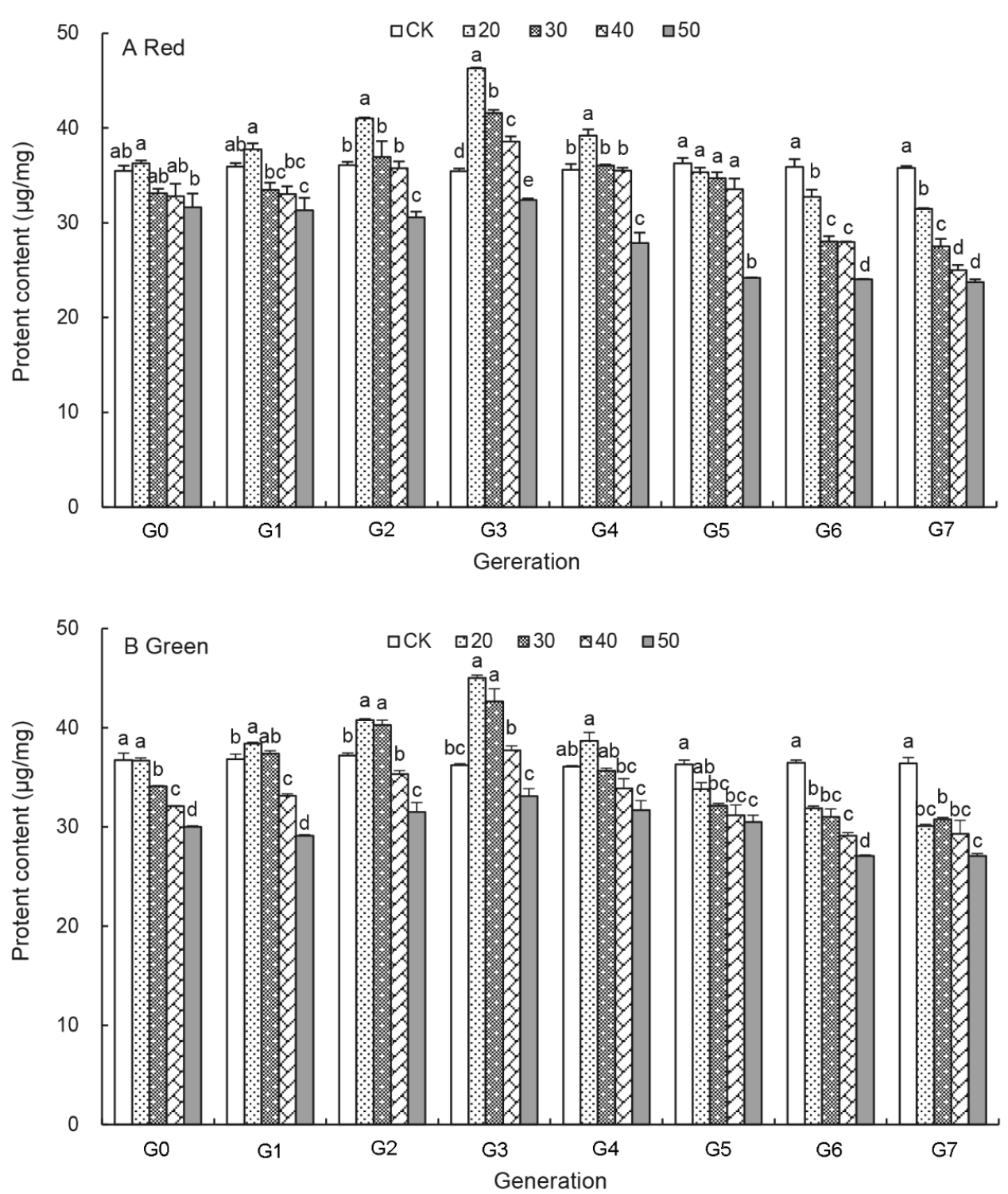

Figure 3. Effects of UV-B radiation on the protein content of A. pisum at each generation $\left(\mathrm{G}_{0}-\mathrm{G}_{7}\right)$. Different lowercase letters between UV-B radiation are statistically different at a same generation in red (A) and green (B) A. pisum ( $p<0.05$, Tukey-HSD test). 


\subsection{Effects of UV-B Treatment on SOD Activity of Aphids}

Figure $4 \mathrm{~A}$ shows the effect of UV-B treatments on the SOD activity of the red aphids. The SOD activity at $G_{0}, G_{1}$ and $G_{2}$ generation was not significantly affected by the 20-40 min UV-B treatments and was significantly higher after $\mathrm{G}_{5}$ generation compared to those of the control aphids. It was significantly increased by the $50 \mathrm{~min}$ UV-B treatment compared to that of the control aphids at each generation (Figure 4A). The SOD activity was highest at $\mathrm{G}_{7}$ generation over the generations and increased as the UV-B treatment duration increased from $17.16 \pm 0.41 \mu \mathrm{g} / \mathrm{mg}$ by the $20 \mathrm{~min}$ treatment to $24.75 \pm 0.69 \mu \mathrm{g} / \mathrm{mg}$ by the 50 min treatment, which are 3.61 and 5.20 times higher than those of the control aphids (Figure 4A).
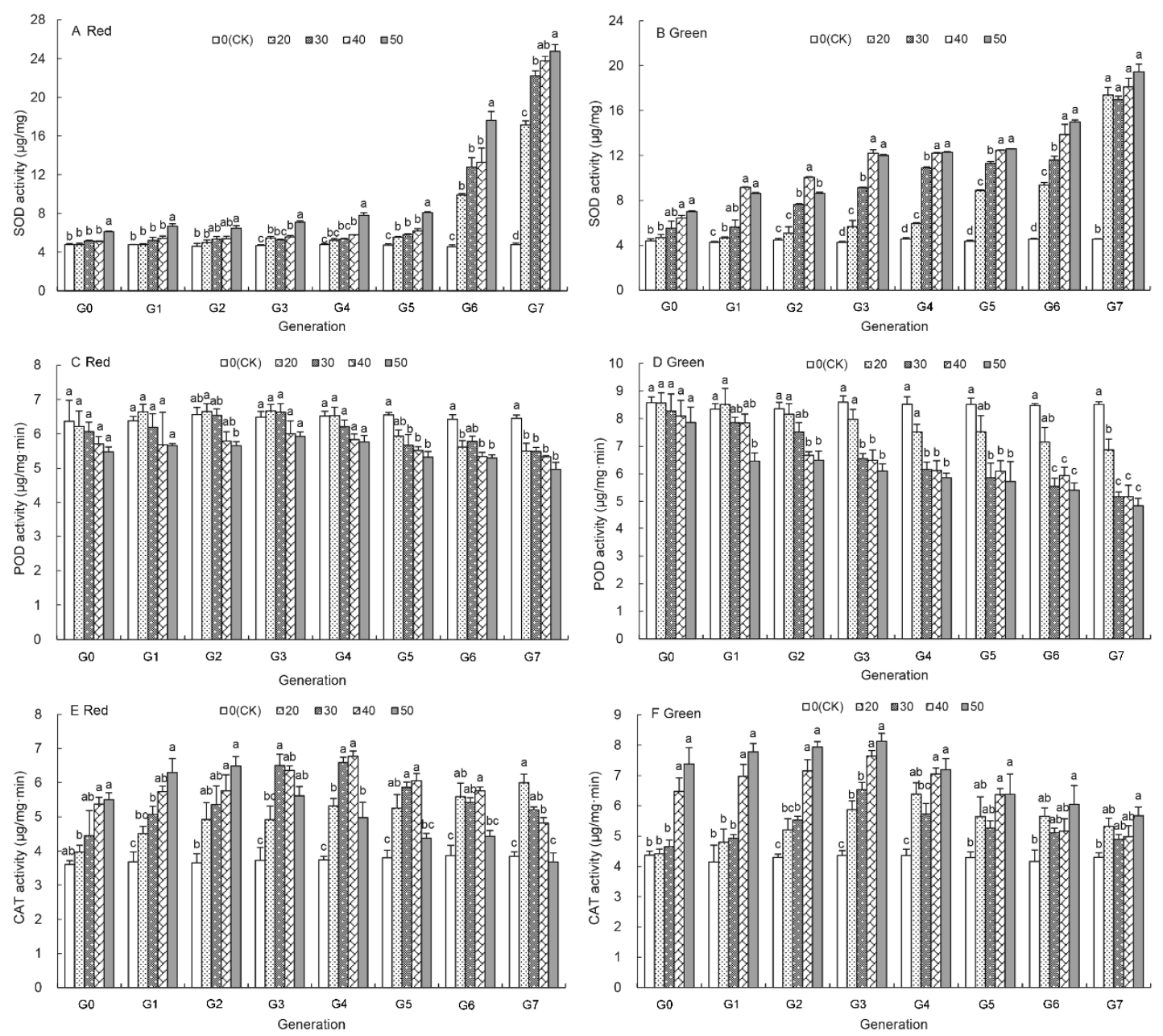

Figure 4. Effects of UV-B radiation on the protect enzyme activity of $A$. pisum at each generation $\left(\mathrm{G}_{0}-\mathrm{G}_{7}\right)$. (A,B): Superoxide dismutase (SOD); (C,D): Peroxidase (POD); (E,F): Catalase (CAT). Different lowercase letters between UV-B radiation are statistically different at a same generation in red $(\mathbf{A}, \mathbf{C}, \mathbf{E})$ and green $(\mathbf{B}, \mathbf{D}, \mathbf{F})$ A. pisum $(p<0.05$, Tukey-HSD test).

Similarly, the SOD activity at each generation of the green aphids increased with the UV-B treatment duration and over generations (Figures 4B and S3B). At the $\mathrm{G}_{7}$ generation it increased by $2.73-3.28 \%$ from that of the control aphids to $17.39 \pm 0.69 \mu \mathrm{g} / \mathrm{mg}$, $16.98 \pm 0.31 \mu \mathrm{g} / \mathrm{mg}, 18.11 \pm 0.77 \mu \mathrm{g} / \mathrm{mg}$ and $19.47 \pm 0.68 \mu \mathrm{g} / \mathrm{mg}$ under the UV-B treatments for $20 \mathrm{~min}, 30 \mathrm{~min}, 40 \mathrm{~min}$, and $50 \mathrm{~min}$, respectively.

\subsection{Effects of UV-B Treatment on the POD Activity of Aphids}

Unlike the activity of other enzymes, the POD activity was reduced by the UV-B treatments (Figure $4 \mathrm{C}, \mathrm{D}$ ). It was significantly lower than that of untreated aphids after 
$\mathrm{G}_{5}$ generation under the $30 \mathrm{~min}$ and $50 \mathrm{~min}$ treatments in the red aphids (Figure 4C) and in the green aphids (Figure $4 \mathrm{D}$ ). At $\mathrm{G}_{7}$ generation, the POD activity of the red and green aphids was reduced by $22.93 \%$ and $43.07 \%$ than that of the control aphids by 50 min UV-B treatment, respectively. Moreover, the POD activity of the red aphids was not significantly changed by the 20-50 min UV-B treatments even at $\mathrm{G}_{7}$ generation, whereas the POD activity of the green aphids was significantly decreased from $8.60 \pm 0.23 \mu \mathrm{g} / \mathrm{mg} \cdot \mathrm{min}$ to $4.85 \pm 0.27 \mu \mathrm{g} / \mathrm{mg} \cdot \mathrm{min}$ after $\mathrm{G}_{3}$ generation by the UV-B treatments (Figures $4 \mathrm{D}$ and $\mathrm{S} 3 \mathrm{C}, \mathrm{D})$.

\subsection{Effects of UV-B Treatment on the CAT Activity of Aphids}

The CAT activity in both untreated red and green aphids remained unchanged over the generations (Figure 4E,F). However, the UV-B treatments resulted in an increase of the CAT activity between $G_{0}$ to $G_{2}$ generations in both colour morphs in a time-dependent fashion with the highest activity in the treated aphids treated for $50 \mathrm{~min}$ (Figure 4E,F). After $\mathrm{G}_{3}$ generation of the red aphids and $\mathrm{G}_{4}$ generation of the green aphids, the CAT activity decreased under the UV-B treatments. However, it was not reduced below the level of the untreated aphids at $\mathrm{G}_{3}-\mathrm{G}_{6}$ generation. At $\mathrm{G}_{6}$ and $\mathrm{G}_{7}$ generation of the green aphids, the CAT activity was still on average higher by $32.01 \%$, and $21.31 \%$ in the $20 \mathrm{~min}$ to 50 min treated aphids than that of the control, respectively (Figure 4F). Only by the $50 \mathrm{~min}$ treatment at $\mathrm{G}_{7}$ generation was the CAT activity of the red aphid reduced below that of the untreated aphids, but they did not differ significantly (Figure 4E).

\subsection{Comparison of $U V-B$ Treatments on Sugar and the Enzyme Activity at $G_{0}$ and $G_{7}$ Generations}

Figure 5 summarizes the effects of the UV-B treatments on the contents of total protein, glycogen and trehalose, and the activity of $\mathrm{CAT}, \mathrm{SOD}$, and $\mathrm{POD}$ at $\mathrm{G}_{0}$ and $\mathrm{G}_{7}$ generations. There was no significant difference in all measured parameters in the untreated aphids at $\mathrm{G}_{0}$ and $\mathrm{G}_{7}$ generations (Figure 5). The UV-B treatments caused an increase in the trehalose content, the glycogen content, the SOD activity, and the CAT activity, and a decrease in the protein content and the POD activity. The 20 min UV-B treatment caused a significant change in the glycogen content, total protein content, and the SOD activity between $\mathrm{G}_{0}$ and $\mathrm{G}_{7}$ generations (Figure $5 \mathrm{~B}-\mathrm{D}$ ). However, the trehalose content, the POD activity, and the CAT activity between $\mathrm{G}_{0}$ and $\mathrm{G}_{7}$ generations were not changed significantly by the 20 min treatment (Figure 5A,E,F). In fact, the trehalose content between the generations was not significantly affected even under the $50 \mathrm{~min}$ treatment for both red and green aphids (Figure 5A). As the UV-B treatment duration increased, the total protein content and the POD activity decreased, while the glycogen content and the SOD activity significantly increased (Figure 5B,D). 

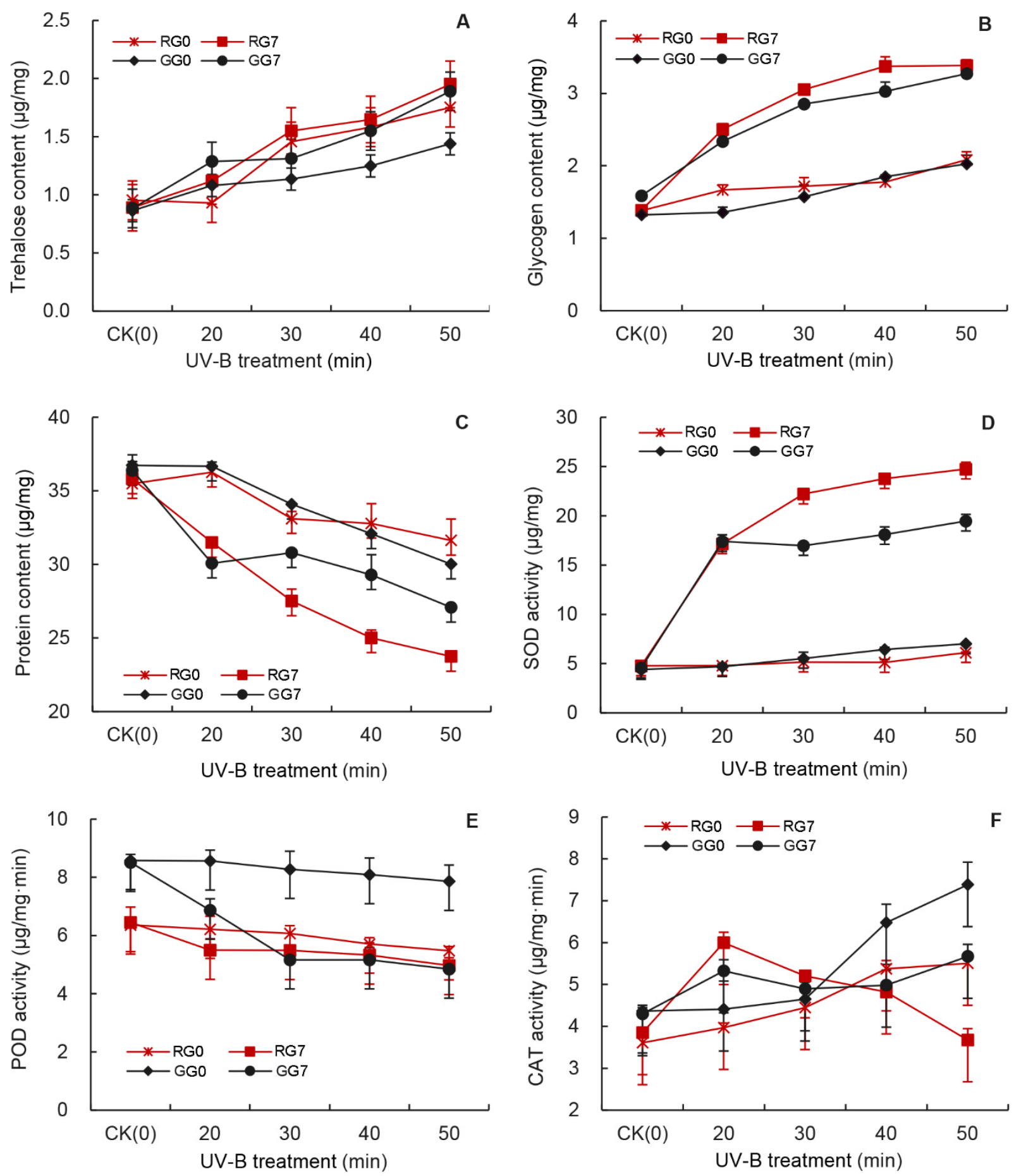

Figure 5. Comparison of UV-B treatment on sugar contents and the activity of protective enzymes of red (R) and green (G) pea aphids at $\mathrm{G}_{0}$ and $\mathrm{G}_{7}$ generations. (A): Trehalose content; (B): Glycogen content; (C): Protein content; (D): Superoxide dismutase (SOD); (E): Peroxidase (POD); (F): Catalase (CAT).

At $G_{7}$ generation, the protein content of the red aphid was lower than that of the green aphid under the $30 \mathrm{~min}$ to $50 \mathrm{~min}$ UV-B treatments, suggesting that the UV-B treatments may have a relatively greater impact on the protein content of the red pea aphids (Figure 5C). On the other hand, the UV-B treatments had a greater effect on the POD activity in the green aphids than in the red aphids (Figure 5E). 


\section{Discussion}

The current study reports the long-term effects and possible mechanisms of UV-B on the protective enzyme activity and nutritional dynamics of the red and green morphs of pea aphids over eight generations.

Energy storage in arthropods has significant implications for survival and reproduction [46]. The primary energy sources are carbohydrates and proteins $[47,48]$. This study reveals a significant increase in the glycogen content after the UV-B treatments over eight generations (Figure 2) consistent with the response of insects to low temperature treatment $[49,50]$. The increase in glycogen content could be an adaptation mechanism of insects to adversity. In other research on A. pisum, the elevated $\mathrm{CO}_{2}$ levels also initiated aphid emergency responses by increasing glucose metabolism [51]. A similar trend was observed in the trehalose content of UV-B treated aphids (Figure 1), participating in the body's energy supply as an energy substance as in diapausing pupae of the silkmoth, Philosamia cynthia [52]. Trehalose is a non-reducing sugar and the principal sugar circulating in the haemolymph of most insects. It also protects insects from the deleterious effects of osmotic, anoxic and other environmental treatments [53-55]. These results suggest that $\mathrm{UV}-\mathrm{B}$ radiation is a negative environmental factor for $A$. pisum.

Our results revealed that the protein contents in the UV-B treated aphids were significantly lower than in control aphids between $G_{0}$ and $G_{3}$ generation, which is consistent with Ahsaei et al., who showed that the reproduction ability of the pea aphid was closely correlated with the protein contents in its body [56]. It is possible that more immune response-related proteins and enzymes were produced under the UV-B radiation. The protein content of insects is for development, maintenance, morphogenesis and reproduction, and cell osmotic pressure $[57,58]$. Based on previous research, protein supplements enhanced Bactrocera minax survival, mating, and fecundity [59]. More interesting, proteins may even be of more importance for aphids as there are three generations present within one viviparous female [60]. As the aphids grew, the long-term UV-B radiation resulted in the inhibition of protein synthesis and protein transportation, the protein content continuously declined from $G_{4}$ to $G_{7}$ generation (Figure 3 and Table S1). These results confirmed that a long period of UV-B treatment led to inhibitory effects on the development and population growth of the pea aphid [39,40].

The green aphid morphs accumulated higher protein than the red aphid morphs under the long-term UV-B radiation (Figure 3), which is in consistent with previous research that the green aphids produced more offspring than the red aphids [61] and that the green morph is considered to be batter adapted to cold conditions than red aphids, because they occur earlier in the vegetative season [62]. However, red aphids are more abundant than the green aphids during warmer months $[63,64]$. The red A. pisum aphids were more sensitive and showed a higher increase in the glycogen contents under the UV-B treatments (Figure 5B). They accumulated significantly more glycogen and trehalose than the green aphids as reported previously [61]. Proteins account for $42.14 \%$ of total energy reserves in the green aphids and $22.06 \%$ in the red aphids [56]. The mechanism for these physiological differences between the red and green aphids is not clear. An increase of energy reserve contents in A. pisum body led to their increased mobility [56]. Interestingly, winged aphids have a lower reproductive potential than apterous individuals [65]. It may be possible that the red pea aphids are more active than the green aphids in terms of dispersal both by walking and flying away from UV-B radiation.

We then further investigated the effects of UV-B treatment on the activities of three protective enzymes in the pea aphid and revealed that the activity of all the assayed protective enzyme was affected in the UV-B treated aphids compared to those in untreated aphids (Figure 4). These enzymes (SOD, POD and CAT), which can effectively inhibit the active oxygen species from damaging and play an important role in maintaining normal functions of living organisms [66]. These three enzymes contribute to keeping cellular free radicals at a normal level, thus abating the damage of free radicals and raising the resistance of in living organisms to exogenous substances [67-70]. The effect 
of the UV-B treatment on the SOD activity increased with generation, but only after $\mathrm{G}_{5}$ generation was the SOD activity significantly increased by all UV-B treatments and reached a maximum level at $50 \mathrm{~min}$ treatment (Supplementary Figure S3A). The UV-B radiation first increased and then decreased the activities of POD in A. pisum, and these decreases were greater with increasing UV-B treatment time (Figure 4C,D), consistent with the finding on Sitobion avenae. [25]. The short-term UV-B treatments promoted the CAT activity of both red and green aphid morphs (Figure $4 \mathrm{E}, \mathrm{F}$ ), probably as a response to overcome UV$\mathrm{B}$-induced oxidative impacts. However, the CAT activity then declined with increasing generation. After the $\mathrm{G}_{4}$ generation, the CAT activity was lower than in the control under 50 min treatments (Supplementary Figure S3E,F). Interestingly, we found that the CAT activity was higher in the green aphids than in the red aphids, but at $\mathrm{G}_{7}$ generation, the activity of SOD and POD was higher in the red aphids than in the green aphids after the UV-B treatments (Figure 5), which may be why the red aphids are more adaptable to UV-B radiation and the fecundity is still lower in the red aphids than in the green aphids.

\section{Conclusions}

In this study, we demonstrated that UV-B radiation can lead to increase sugar contents in both red and green morphs of $A$. pisum, and confirmed the effects of UV-B radiation on the aphid physiology by means of regulating the protective enzyme activity. More interestingly, our study discovered the differences between the red and green aphids in response of UV-B radiations. Moreover, the sugar content, and protective enzymes (SOD and POD) activity of the red pea aphid are greater than those of the green pea aphid in long-term UV-B radiation, indicating the red aphid may be more adaptable to ultraviolet radiation.

Supplementary Materials: The following are available online at https:/ /www.mdpi.com/article/10 $.3390 /$ insects12121053/s1, Table S1: Average content $(\mu \mathrm{g} / \mathrm{mg})$ of total protein, Figure S1: Effects of UV-B radiation on trehalose content of Acyrthosiphon pisum for eight $\left(\mathrm{G}_{0}-\mathrm{G}_{7}\right)$ generations, Figure S2: Effects of UV-B radiation on glycogen content of Acyrthosiphon pisum for eight $\left(\mathrm{G}_{0}-\mathrm{G}_{7}\right)$ generations, Figure S3: Effects of UV-B radiation on the protect enzyme activity of Acyrthosiphon pisum at each of eight generations $\left(\mathrm{G}_{0}-\mathrm{G}_{7}\right)$.

Author Contributions: Author Contributions: Project conceptualisation and management: C.L. (Chunchun Li), W.Y. and C.L. (Changzhong Liu) Method-ology and sampling: C.L. (Chunchun Li), W.Y., Y.G., K.Z. and Q.Z. Data analysis: C.L. (Chunchun Li), W.Y., J.-J.Z. and C.L. (Changzhong Liu) Visualisation and validation: K.Z., Q.Z., J.-J.Z. and C.L. (Changzhong Liu) Writing and reviewing the manuscript: C.L. (Chunchun Li), W.Y., Y.G., K.Z., Q.Z., J.-J.Z. and C.L. (Changzhong Liu) All authors have read and agreed to the published version of the manuscript.

Funding: This research was funded by the National Science Foundation of China (No. 31960351, 31260433, 31960227). Gansu Province excellent graduate "Innovation Star" project of China (2021CXZX-379) to C.L. Program of Introducing Talents to Chinese Universities (111 Program no. D20023) to J.-J.Z.

Institutional Review Board Statement: Not applicable.

Informed Consent Statement: Not applicable.

Data Availability Statement: The datasets in this study are available from the corresponding author on reasonable request.

Acknowledgments: We would like to acknowledge the contributions made by Wang Lixiang, Li Yan in experimental data analysis.

Conflicts of Interest: The authors declare no competing interests.

\section{References}

1. Madronich, S.; McKenzie, R.L.; Caldwell, M.M.; Bjorn, L.O.; Li, W. The changes of surface ultraviolet radiation. AMBIO J. Hum. Environ. 1995, 24, 143-152. 
2. Long, C.S.; Miller, A.J.; Lee, H.T.; Wild, J.D.; Przywarty, R.C.; Hufford, D. Ultraviolet index forecasts issued by the National Weather Service. Bull. Am. Meteorol. Soc. 1996, 77, 729-748. [CrossRef]

3. Potter, K.A.; Woods, H.A. Immobile and tough versus mobile and weak: Effects of ultraviolet B radiation on eggs and larvae of Manduca sexta. Physiol. Entomol. 2013, 38, 246-252. [CrossRef]

4. Osakabe, M. Biological impact of ultraviolet-B radiation on spider mites and its application in integrated pest management. Appl. Entomol. Zool. 2021, 56, 139-155. [CrossRef]

5. Villena, O.C.; Momen, B.; Sullivan, J.; Leisnham, P.T. Effects of ultraviolet radiation on metabolic rate and fitness of Aedes albopictus and Culex pipiens mosquitoes. PeerJ 2018, 6, e6133. [CrossRef]

6. Crutzen, P.J. Ultraviolet on the increase. Nature 1992, 356, 104-105. [CrossRef]

7. Madronich, S.; McKenzie, R.L.; Bjorn, L.O.; Caldwell, M.M. Changes in biologically active ultraviolet radiation reaching the Earth's surface. J. Photochem. Photobiol. B Biol. 1998, 46, 5-19. [CrossRef]

8. Andrady, A.L.; Hamid, H.S.; Hu, X.; Torikai, A. Effects of increased solar ultraviolet radiation on materials. J. Photochem. Photobiol. 1998, 46, 96-103. [CrossRef]

9. Rebollar, E.; Valadez-Graham, V.; Vázquez, M.; Reynaud, E.; Zurita, M. Role of the p53 homologue from Drosophila melanogaster in the maintenance of histone $\mathrm{H} 3$ acetylation and response to UV-light irradiation. FEBS Lett. 2006, 580, 642-648. [CrossRef]

10. Pitzschke, A.; Forzani, C.; Hirt, H. Reactive oxygen species signaling in plants. Antioxid. Redox Signal. 2006, 8, 1757-1764. [CrossRef]

11. Jenkins, G.I. Signal transduction in responses to UV-B radiation. Annu. Rev. Plant Biol. 2009, 60, 407-431. [CrossRef]

12. Gill, S.S.; Tuteja, N. Reactive oxygen species and antioxidant machinery in abiotic stress tolerance in crop plants. Plant Physiol. Biochem. 2010, 48, 909-930. [CrossRef] [PubMed]

13. Tuncbilek, A.S.; Ercan, F.S.; Canpolat, U. Effect of ionizing (gamma) and non-ionizing (UV) radiation on the development of Trichogramma euproctidis (Hymenoptera: Trichogrammatidae). Arch. Biol. Sci. 2012, 64, 287-295. [CrossRef]

14. Lidon, F.C.; Teixeira, M.; Ramalho, J.C. Decay of the chloroplast pool of ascorbate switches on the oxidative burst in UV-Birradiated rice. J. Agron. Crop Sci. 2012, 198, 130-144. [CrossRef]

15. Zeni-Graiff, M.; Rios, A.C.; Maurya, P.K.; Rizzo, L.B.; Sethi, S.; Yamagata, A.S.; Mansur, R.B.; Pan, P.M.; Asevedo, E.; Cunha, G.R.; et al. Peripheral levels of superoxide dismutase and glutathione peroxidase in youths in ultra-high risk for psychosis: A pilot study. CNS Spectr. 2019, 24, 333-337. [CrossRef]

16. Lozinskaya, Y.L.; Slepneva, I.A.; Khramtsov, V.V.; Glupov, V.V. Changes of the antioxidant status and system of generation of free radicals in hemolymph of Galleria mellonella larvae at microsporidiosis. J. Evol. Biochem. Physiol. 2004, 40, 119-125. [CrossRef]

17. Meng, J.Y.; Zhang, C.Y.; Zhu, F.; Wang, X.P.; Lei, C.L. Ultraviolet light-induced oxidative stress: Effects on antioxidant response of Helicoverpa armigera adults. J. Insect Physiol. 2009, 55, 588-592. [CrossRef] [PubMed]

18. Kumar, J.; Ghosh, P.; Kumar, A. Ultraviolet-B radiation stress-induced toxicity and alterations in proteome of Deinococcus radiodurans. Adv. Microb. Physiol. 2020, 31, 1-15. [CrossRef] [PubMed]

19. Lu, F.P.; Chen, Q.; Chen, Z.S.; Lu, H.; Xu, X.L.; Jing, F.L. Effects of heat stress on development, reproduction and activities of protective enzymes in Mononychellus mcgregori. Exp. Appl. Acarol. 2014, 63, 267-284. [CrossRef]

20. Qin, D.Q.; Liu, B.J.; Zhang, P.W.; Zheng, Q.; Luo, P.R.; Ye, C.Y.; Zhao, W.H.; Zhang, Z.X. Treating green pea aphids, Myzus persicae, with azadirachtin affects the predatory ability and protective enzyme activity of harlequin ladybirds, Harmonia axyridis. Ecotoxicol. Environ. Saf. 2021, 212, 111984. [CrossRef]

21. Huang, A.L.; Meng, L.Y.; Zhang, W.; Liu, J.Y.; Li, G.Y.; Tan, H.H.; Lu, W.; Zheng, X.L. Effects of five pesticides on toxicity, detoxifying and protective enzymes in Phauda flammans Walker (Lepidoptera: Zygaenidae). Pak. J. Zool. 2019, 51, 1457-1463. [CrossRef]

22. Ding, J.N.; Zhang, H.H.; Chi, D.F. Effects of a pathogenic Beauveria bassiana (Hypocreales: Cordycipitaceae) strain on detoxifying and protective enzyme activities in Xylotrechus rusticus (Coleoptera: Cerambycidae) larvae. Fla. Entomol. 2015, 98, 1148-1156. [CrossRef]

23. Dubovskiy, I.M.; Martemyanov, V.V.; Vorontsova, Y.L.; Rantala, M.J.; Gryzanova, E.V.; Glupov, V.V. Effect of bacterial infection on antioxidant activity and lipid peroxidation in the midgut of Galleria mellonella L. larvae (Lepidoptera, Pyralidae). Comp. Biochem. Physiol. Part C: Toxicol. Pharmacol. 2008, 148, 1-5. [CrossRef] [PubMed]

24. Kayser, H.; Palivan, C.G. Stable free radicals in insect cuticles: Electron spin resonance spectroscopy reveals differences between melanization and sclerotization. Arch. Biochem. Biophys. 2006, 453, 179-187. [CrossRef] [PubMed]

25. Zhou, D.; Du, Y.M.; Yang, J.; Zhang, L.; Zhao, H.Y.; Hu, Z.Q.; Hu, X.S. Effects of UV-B radiation in successive generations on the activities of protective enzymes in the grain aphid, Sitobion avenae (Hemiptera: Aphididae). Acta Entomol. Sin. 2014, 57, 762-768.

26. Bournoville, R. Insectes ravageurs des legumineuses. In Ennemiset Maladies des Prairies; Raynal, G., Gondran, J., Bournoville, R., Courtillot, M., Eds.; Editions Quae: Versailles, France, 1989; pp. 179-195.

27. Harrington, C.D. Biological races of the pea aphid. J. Econ. Entomol. 1945, 38, 12-22. [CrossRef]

28. Losey, J.E.; Ives, A.R.; Harmon, J.; Browm, C.; Ballantyne, F. A polymorphism maintained by opposite patterns of parasitism and predation. Nature 1997, 388, 269-272. [CrossRef]

29. Caillaud, M.C.; Losey, J.E. Genetics of color polymorphism in the pea aphid, Acyrthosiphon pisum. J. Insect Sci. 2010, 10, 95. [CrossRef] 
30. Tsuchida, T.; Koga, R.; Horikawa, M.; Tsunoda, T.; Maoka, T.; Matsumoto, S.; Simon, J.C.; Fukatsu, T. Symbiotic bacterium modifies aphid body color. Science 2010, 330, 1102-1104. [CrossRef]

31. Sang, W.; Yu, L.; He, L.; Ma, W.H.; Zhu, Z.H.; Zhu, F.; Wang, X.P.; Lei, C.L. UVB radiation delays Tribolium castaneum metamorphosis by influencing ecdysteroid metabolism. PLoS ONE 2016, 11, e0151831. [CrossRef]

32. Ryalls, J.M.W.; Riegler, M.; Moore, B.D.; Johnson, S.N. Biology and trophic interactions of lucerne aphids. Agric. For. Entomol. 2013, 15, 335-350. [CrossRef]

33. Makkouk, K. Viruses and virus diseases of pea, lentil, faba bean and chickpea. World Crops: Cool Seas. Food Legum. 1988, 5, 591-615.

34. Du, J.L.; Wu, D.G.; Zhang, T.W.; Qian, X.J.; Liu, C.Z. Effect of UV-B for different radiation durations on biological characteristics of two color morphs of pea aphid Acyrthosiphon pisum (Harris) offspring. Acta Agresti. Sin. 2012, 20, 961-966.

35. Lv, N.; Wang, L.; Sang, W.; Liu, C.Z.; Qiu, B.L. Effects of endosymbiont disruption on the nutritional dynamics of the pea aphid Acyrthosiphon pisum. Insects 2018, 9, 161. [CrossRef]

36. Barberà, M.; Rubén, C.C.; David, M.T. Insulin-like peptides in volved in photoperiodism in the aphid Acyrthosiphon pisum. Insect Biochem. Mol. Biol. 2019, 112, 103185. [CrossRef]

37. Wang, G.; Guo, Y.P.; Guo, S.F.; Zhou, J.J.; Liu, C.Z. RNA interference of trehalose-6-phosphate synthase and trehalase genes regulates chitin metabolism in two color morphs of Acyrthosiphon pisum Harris. Sci. Rep. 2021, 11, 948. [CrossRef] [PubMed]

38. Wang, G.; Zhou, J.J.; Li, Y.; Guo, Y.P.; Quandahor, P.; Liu, C.Z. Trehalose and glucose levels regulate feeding behavior of the phloem-feeding insect, the pea aphid Acyrthosiphon pisum Harris. Sci. Rep. 2021, 11, 15864. [CrossRef]

39. Yuan, W.N.; Lv, N.; Sun, X.L.; Liu, C.Z. Effects of continuous UV-B stress on biological characteristics of green pea aphid. Chin. J. Eco-Agric. 2015, 23, 1020-1025.

40. Yuan, W.N.; Zhu, Y.Y.; Sun, X.L.; Yang, Q.Y.; Liu, C.Z. Effects of UV-B stress on biological characteristics of red pea aphid Acyrthosiphon pisum Harris. Plant Prot. 2016, 42, 77-82.

41. Handel, V.E.; Day, J.F. Assay of lipids, glycogen and sugars in individual mosquitoes: Correlations with wing length in fieldcollected Aedes vexans. J. Am. Mosq. Control. Assoc. 1988, 4, 549-550.

42. Lowry, B.O.H.; Rosebroug, N.J.; Farr, A.L.; Randdall, R.J. Protein measurement with the Folin phenol reagent. J. Biol. Chem. 1951, 193, 256-275. [CrossRef]

43. Beauchamp, C.; Fridovich, I. Superoxide dismutase: Improved assays and an assay applicable to acrylamide gels. Anal. Biochem. 1971, 44, 276-287. [CrossRef]

44. Chance, P.; Maehly, A.C. Assay of catalases and peroxidases. Meth. Enzymol. 1955, 11, 764-775.

45. Shan, W.; Li, Y.L.; Zhu, J.J.; Liang, Y.H.; Wang, Z.M. Effect of different sulfur fumigation dosages on activity of browning enzymes and chemical constituents of Chrysanthemum morifolium cv. Boju. Chin. Med. J. 2019, 44, 4852-4856.

46. Lease, H.M.; Wolf, B.O. Lipid content of terrestrial arthropods in relation to body size, phylogeny, ontogeny and sex. Physiol. Entomol. 2011, 36, 29-38. [CrossRef]

47. Beenakkers, A.M.T.; Van der Horst, D.J.; Van Marrewijk, W.J.A. Insect lipids and lipoproteins, and their role in physiological processes. Prog. Lipid Res. 1985, 24, 19-67. [CrossRef]

48. O'Brien, D.M. Fuel use in flight and its dependence on nectar feeding in the hawkmoth Amphion floridensis. J. Exp. Biol. 1999, 202, 441-451. [CrossRef] [PubMed]

49. Tsonev, L.I.; Tihova, M.G.; Brain, A.P.R.; Yu, Z.W.; Quinn, P.J. The effect of the cryoprotective sugar trehalose on the phase behaviour of mixed dispersions of dioleoyl derivatives of phosphatidylethanolamine and phosphatidylcholine. Liq. Cryst. 1994, 17, 717-728. [CrossRef]

50. Womersley, C.Z.; Higa, L.M. Trehalose: Its role in the anhydrobiotic survival of Ditylenchus myceliophagus. Nematologica 1998, 44, 269-292.

51. Li, C.C.; Sun, Q.; Gou, Y.P.; Zhang, K.X.; Zhang, Q.Y.; Zhou, J.J.; Liu, C.Z. Long-term effect of elevated CO ${ }_{2}$ on the development and nutrition contents of the Pea Aphid (Acyrthosiphon pisum). Front. Physiol. 2021, 12, 827. [CrossRef]

52. Hawakawa, Y.; Chino, H. Temperature-dependent activation or inactivation of glycogen phosphorylase and synthase of fat body of the silkworm Philosamia cynthia: The possible mechanism of the temperature-dependent interconversion between glycogen and trehalose. Insect Biochem. 1982, 12, 361-366. [CrossRef]

53. Storey, K.B.; Storey, J.M. Freeze tolerance in animals. Physiol. Rev. 1988, 68, 27-84. [CrossRef]

54. Uritani, M.; Takai, M.; Yoshinaga, K. Protective effect of disaccharides on restriction endonucleases during drying under vacuum. J. Biochem. 1995, 117, 774-779. [CrossRef] [PubMed]

55. Crowe, J.H.; Crowe, L.M.; Oliver, A.E.; Tsvetkova, N.; Wolkers, W.; Tablin, F. The trehalose myth revisited: Introduction to a symposium on stabilization of cells in the dry state. Cryobiology 2001, 43, 89-105. [CrossRef]

56. Ahsaei, S.M.; Tabadkani, S.M.; Hosseininaveh, V.; Allahyari, H.; Bigham, M. Differential accumulation of energy by the colour morphs of the pea aphid Acyrthosiphon pisum (Hemiptera: Aphididae) mirrors their ecological adaptations. Eur. J. Entomol. 2013, 110, 241-245. [CrossRef]

57. Wang, D.; Xuan, J.P.; Guo, H.L.; Liu, J.X. Seasonal changes of freezing tolerance and its relationship to the contents of carbohydrates, proline, and soluble protein of Zoysia. Acta Prataculturae Sin. 2011, 20, 98-107.

58. Moeini, P.; Tahmasebi, A. Maize Iranian mosaic virus infection promotes the energy sources of its insect vector, Laodelphax striatellus. J. Appl. Entomol. 2018, 143, 271-276. [CrossRef] 
59. Wang, F.L.; Chambi, C.; Li, Z.Y.; Huang, C.; Ma, Y.K.; Li, C.R.; Tian, X.H.; Sangija, F.; Ntambo, M.S.; Kankonda, O.M.; et al. Influence of supplemental protein on the life expectancy and reproduction of the Chinese Citrus Fruit Fly, Bactrocera minax (Enderlein) (Tetradacus minax) (Diptera: Tephritidae). J. Insect Sci. 2018, 18, 25. [CrossRef] [PubMed]

60. Stevens, N.M. A study of the germ cells of Aphis rosae and Aphis oenotherae. J. Exp. Zool. 1905, 2, 313-333. [CrossRef]

61. Markkula, M. Studies on the pea aphid, Acyrthosiphon pisum, with special reference to the differences in the biology of the green and red forms. Ann. Agric. Fenn. 1963, 2, 1-30.

62. Valmalette, J.C.; Dombrovsky, A.; Brat, P.; Mertz, C.; Capovilla, M.; Robichon, A. Light-induced electron transfer and ATP synthesis in a carotene synthesizing insect. Sci. Rep. 2012, 2, 1-8. [CrossRef] [PubMed]

63. Weisser, W.W.; Braendle, C. Body color and genetic variation in winged morph production in the pea aphid. Entomol. Exp. Appl. 2001, 99, 217-223. [CrossRef]

64. Jin, J.; Wang, S.S.; He, C.G. Genetic diversities of Acyrthosiphon pisum (harris) (pink form) populations from different geographic regions in the northwest of China. Acta Agrestia Sin. 2013, 21, 406-412.

65. Raikhel, A.S.; Dhadialla, T.S. Accumulation of yolk proteins in insect oocytes. Annu. Rev. Entomol. 1992, 37, 217-251. [CrossRef]

66. Wei, H.; Zhikuan, J.; Qingfang, H. Effects of herbivore stress by Aphis medicaginis Koch on the malondialdehyde contents and the activities of protective enzymes in different alfalfa varieties. Acta Ecol. Sin. 2007, 27, 2177-2183. [CrossRef]

67. Orr, W.C.; Sohal, R.S. Extension of life span by overexpression of superoxide dismutase and catalase in Drosophila melanogaster. Science 1994, 263, 1128-1130. [CrossRef]

68. Orr, W.C.; Sohal, R.S. Does overexpression of $\mathrm{Cu}, \mathrm{Zn}-\mathrm{SOD}$ extend life span in Drosophila melanogaster? Exp. Gerontol. 2003, 38, 227-230. [CrossRef]

69. Sohal, R.S.; Agarwal, A.; Agarwal, S.; Orr, W.C. Simultaneous overexpression of copper- and Zinc-containing superoxide dismutase and catalase retards age-related oxidative damage and increases metabolic potential in Drosophila melanogaster. J. Biol. Chem. 1995, 270, 15671-15674. [CrossRef]

70. Bruce, R.J.; West, C.A. Elicitation of lignin biosynthesis and isoperoxidase activity by pectic fragnents in suspension cultures caster bean. Plant Physiol. 1989, 91, 889-897. [CrossRef] 